\title{
The impact of clinical pharmacists in improving Jordanian patients' health outcomes
}

Eman A. Hammad, MSc, PhD, Rajaa A. Qudah, BSc, MSc, Amal A. Akour, BSc, PhD.

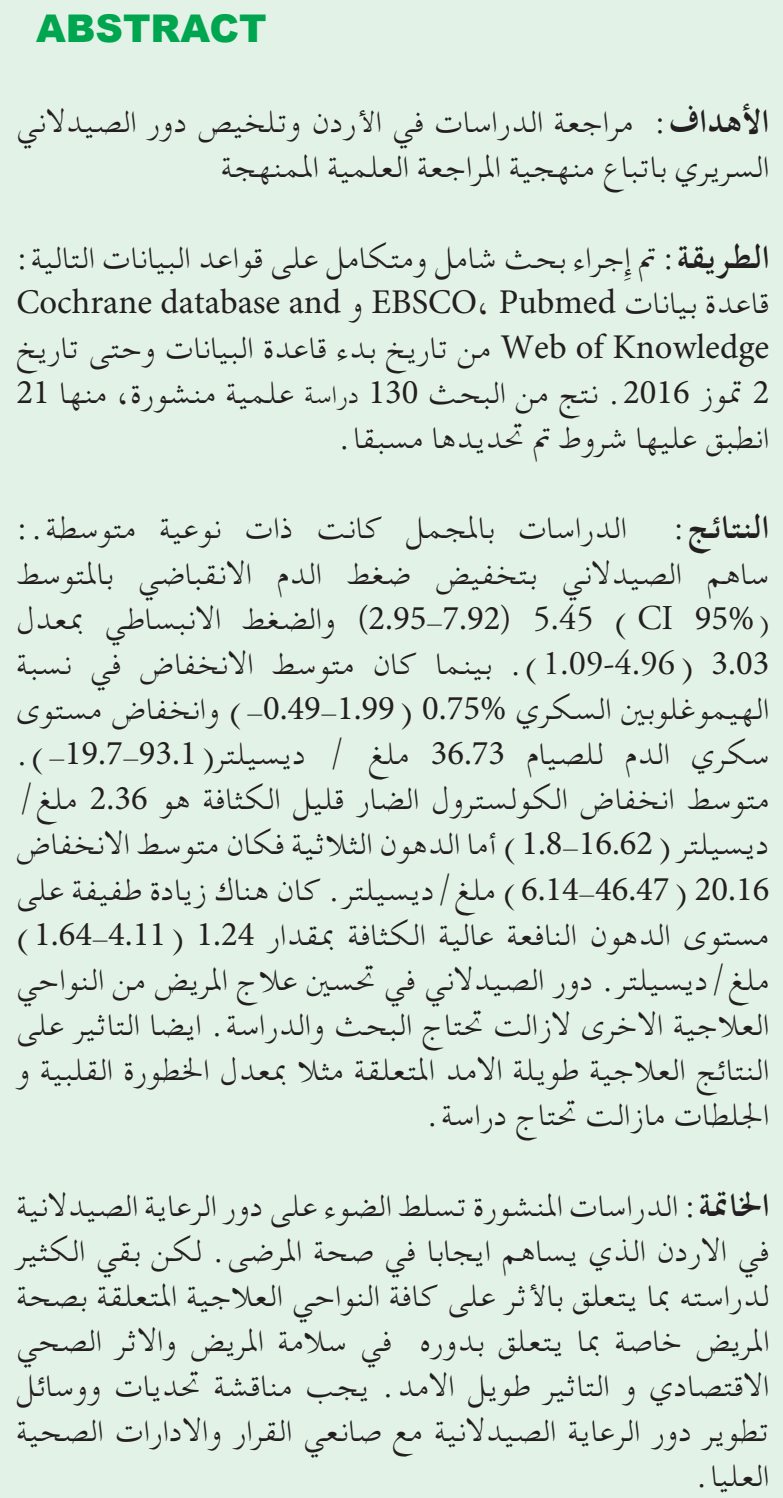

Objectives: To assess the impacts of clinical pharmacists on Jordanian patients' health outcomes.

Methods: A systematic review was conducted until July 2016 within EBSCO, Pubmed, Cochrane database, and ISI Web of Knowledge. Published studies evaluating the benefit of clinical pharmacy services on therapeutic, safety, humanistic, and economic outcomes in hospital or community settings in Jordan were targeted. Two reviewers independently extracted and assessed risk of bias using a pre-published validated tool. The literature search identified 130 publications of which 21 full texts met predetermined inclusion criteria.

Results: Studies were of moderate quality. Pharmacist interventions resulted in an average reduction $(95 \% \mathrm{CI})$ in systolic blood pressure of $5.45 \mathrm{~mm} \mathrm{Hg}(2.95-7.92)$ and diastolic blood pressure of $3.03 \mathrm{~mm} \mathrm{Hg}$ (1.09-4.96). The mean reduction in glycosylated hemoglobin was $0.75 \%(-0.49-1.99)$ and fasting blood sugar was $36.73 \mathrm{mg} / \mathrm{dl}(-19.7-93.1)$. The average reduction in low-density lipoprotein cholesterol was 2.36 (1.8-16.62) $\mathrm{mg} / \mathrm{dl}$ and triglycerides was 20.16 (6.14-46.47). There was a minimal increase in the level of high-density lipoprotein cholesterol of $1.24(1.64-4.11) \mathrm{mg} / \mathrm{dl}$. Effects on safety along with humanistic and economic outcomes and long term effects remained unclear.

Conclusion: Published evidence from Jordan highlights service opportunities for clinical pharmacists. Favorable but not always statistically significant impacts were found on therapeutic outcomes. More studies are needed to understand safety, humanistic, economic, and long-term outcomes. Therefore, the add-on benefits of this service to the health system are not well understood. Future studies of higher rigor and multi-perspective outcomes are mandated.

$$
\begin{array}{r}
\text { Saudi Med J 2017; Vol. } 38 \text { (11): 1077-1089 } \\
\text { doi: 10.15537/smj.2017.11.21453 }
\end{array}
$$

From the Department of Biopharmaceutics and Clinical Pharmacy (Hammad, Akour), Faculty of Pharmacy, University of Jordan, and the Department of Clinical Pharmacy and Therapeutics (Qudah), Faculty of Pharmacy, Applied Science University, Amman, Jordan.

Address correspondence and reprint request to: Dr. Eman A. Hammad, Department of Biopharmaceutics and Clinical Pharmacy, Faculty of Pharmacy, University of Jordan, Amman, Jordan. E-mail:e.hammad@ju.edu.jo

ORCID ID: orcid.org/0000-0003-2059-6473 
$\mathrm{O}$ ver the past 5 decades, the pharmacist profession has advanced from sole dispensary roles to patient oriented clinical services. ${ }^{1,2}$ Herein, pharmacists in most developed countries are empowered to play significant roles in pharmaceutical care services. ${ }^{3}$ However, the role of pharmacists in developing countries is toddling slowly toward a direct collaboration with other health professionals in patient bedside care. In the meantime, they still deal mainly with the preparation and supply of medicines. ${ }^{4-8}$ Early in the 1930s, modern pharmacy practice in the Hashemite, Kingdom of Jordan was started. The first independent community pharmacy opened in $1946 .{ }^{6}$ Since then, pharmacies in Jordan have been thriving. ${ }^{9}$ The number of community pharmacies has exceeded 2,200 and the active workforce is estimated at approximately 12,000 pharmacists. Pharmacy education has also witnessed parallel advances; the total number of licensed pharmacy schools in 2015 was 15 of which 5 are public and 10 private schools. These institutions offer a 5-year Bachelor of Science (BSc) in Pharmacy and 2 of them have offered a 6-year Doctor of Pharmacy (Pharm.D.) degree since 2000. The BSc is considered the main national program. A Master (MSc) program in clinical pharmacy has also offered in 2 of the biggest public universities since 2005. The introduction of the Pharm.D. program and the MSc program in clinical pharmacy has placed great emphasis on the clinical roles of pharmacists in Jordan. ${ }^{4,7,8}$ Studies have consequently started to highlight potentials for advancement in pharmacy practice to involve more bedside activities, patient consultations, and therapy optimization.

However, published studies progressively indicate that the role of pharmacists as members of the health care team has been expanding slowly and outline an existing mismatch between the intended role of graduates and actual job fulfillment. ${ }^{9-26}$ Published reviews attempting to evaluate the literature on the effects of the interventions by clinical pharmacists on processes and outcomes of care in the US and other countries have highlighted that pharmacist-provided direct patient care has favorable effects across various patient outcomes, health care settings, and disease states. Incorporating pharmacists as health care team members in direct patient care was recommended as a viable solution to help improve

Disclosure. Authors have no conflict of interests, and the work was not supported or funded by any drug company. The study protocol was registered with PROSPERO no CRD42015013533. health care and patient outcomes. ${ }^{1-3}$ A Cochrane review in 2013 examined the effect of pharmacist-provided non-dispensing services on patient outcomes, health service utilization, and costs in low- and middle-income countries. ${ }^{27}$ Authors concluded that pharmacistprovided services that target patients may improve clinical outcomes such as management of high glucose levels and blood pressure (BP), but they were uncertain about the impacts on health service utilization and costs due to a lack of evidence. Studies from middleincome countries in Eastern Europe, Africa, and southeast Asia were included in the review. The review results were found to be heterogeneous in the types of outcomes measured, health settings, clinical conditions, and approaches to measurement of outcomes; thus cautious interpretation was recommended. Therefore, the results may not be applicable to low-income eastern Mediterranean countries such as Jordan, which was recently classified as one by the World Bank. The true impact of clinical pharmacists, and thus service uptake, is not well established in Jordan. Stakeholders' and service users' understanding of the add-on benefits of clinical pharmacists and the needed drivers to advance the practice might be lacking. Therefore, the aim of this systematic review is to summarize the impacts of clinical pharmacists' interventions on therapeutic, humanistic, and economic outcomes, compared to the standard care with no pharmacist involvement in direct patient care for Jordanian patients.

Methods. Information sources and review eligibility. The Population, Intervention, Comparison, and Outcome (PICOS) strategy was employed to obtain relevant literature from the following databases: EBSCO (1944), PubMed (1996), Cochrane database, and ISI Web of Knowledge (1990) from the starting date of the database up to July 2, 2016. Search strategy was reviewed, discussed, and face validated by peer researchers and refined accordingly. Participants were patients from Jordan who received pharmacy direct care service aimed to optimize care or therapy outcomes. Inclusion criteria were interventional as well as observational studies performed in community or hospital settings, describing long and short add-on benefits of clinical pharmacy service on process, therapeutic, safety, humanistic, and economic outcomes. Articles were included if they were available as full-text, original, and written in English. Exclusion criteria included studies that were not conducted in Jordan, qualitative studies with no pharmacist involvement, and studies that had not evaluated process or patient related outcomes. 
Search terms and search strategy are available in a supplementary file. Additionally, bibliographies and citations were searched using the SCOPUS database, and reference lists of the identified studies were handsearched. Public and private pharmaceutical schools were contacted via email to obtain any relevant published or accepted for publication work. University and academic institution websites along with the archives of local university affiliated journals were also searched manually for primary and reference literature.

Data extraction and synthesis. Screening and data extraction were performed independently by 2 of the authors using face validated tools developed for the purpose of the review. Discrepancies were resolved through discussion until consensus. Data collected were related to study design, duration, patient characteristics, sample size, study site and settings, intervention and control details, and outcomes measured. Outcome data were related to process outcomes including treatment related problems (TRPs) and patient outcomes including therapeutic, safety, humanistic, and economic. Each study was considered a unit of analysis. Studies reporting multiple outcomes were included in the analysis for each outcome. ${ }^{2}$

Summary outcome data were pooled from comparative studies using the mean difference between the intervention and control groups. Where there were at least 2 studies reporting the same outcome (namely, $\mathrm{mm} \mathrm{Hg}$ for blood pressure), the results were pooled. Data were entered into a pre-published Microsoft Office Excel template using a random effects model to weight studies based on sample size calculated at $95 \%$ confidence intervals (CI) for the mean difference for each study included in the analysis. ${ }^{28}$ Heterogeneity was investigated using the Q-statistic and the $\mathrm{I}^{2}$ index, which represents the percentage of total variation across studies due to heterogeneity rather than chance. The $\mathrm{I}^{2}$ index was calculated using (Q-df)/Q x 100\% where $\mathrm{Q}$ is the Cochran's heterogeneity statistic and $\left(\mathrm{I}^{2}\right) \mathrm{w} \mathrm{I}^{2}$ $>50 \%$ is considered a high value. Kendall's tau statistic was calculated to assess publication bias. ${ }^{2}$

Assessment of risk of bias. Two reviewers independently assessed the risk of bias against 8 out of 9 bias domains defined and validated previously. ${ }^{29}$ Those are: design bias, selection bias, randomization, standardized intervention delivery, standardized measurement, blindness of outcome measurement, incomplete data, and adequacy of study power. One of the domains was omitted; concealment of allocation. It was agreed that direct participation of pharmacists in patient care and contact with the health team would hinder the researcher's ability to conceal the patient allocation to the study groups, thus studies were not scored against this domain. ${ }^{29,30}$

Results. The literature search identified 130 publications, of which 40 and 58 studies were excluded after removing duplicates and title/abstract screening respectively. Consequently, 32 studies were subject to full text screening. Of these, 21 studies met the inclusion criteria and included in the review. The study selection process is illustrated in Figure 1. Studies characteristics and outcomes measured are presented in Table 1.

Twelve studies evaluated process outcomes, TRPs, and pharmacist interventions. ${ }^{9} 13,14,17,18,20,32,34,35,37-39$ Therapeutic outcomes were reported in 9 studies. ${ }^{10,20,23,30-35}$ Eleven studies reported humanistic outcomes. ${ }^{10,13,16,17,22-24,33,35-37}$ Only one study reported economic outcomes ${ }^{12}$ while 2 studies reported safety outcomes. ${ }^{20,32}$ Mixed outcome areas were reported in 6 studies. ${ }^{10,20,23,32,35,36}$

A total of 6,205 patients were included, adults aged over 18 years old. Further details on the characteristics of the included patients are presented in Appendix 1. One study was conducted in pediatric wards; however, patient age was not reported. ${ }^{16}$ Studies evaluated various chronic disease areas including hypertension, diabetes mellitus, kidney disease, chronic obstructive pulmonary disease (COPD), infectious disease, and cancer.

Most studies were of moderate quality ${ }^{9,11,12,14,17,20,23,31,32,34,36}$ and 3 were scored at high quality. ${ }^{10,24,37}$ Studies often showed methodological strength with respect to standardized delivery of the intervention and outcome measurement. On the other hand, there was no or little information about the blindness of the outcome measurement; therefore, bias judgment was unclear to high risk. Assessment of bias risk per study and per bias domain are presented in Figures 2 and 3 . The median overall quality score (range) was $56.3 \%$ (-35.7\% to $100 \%)$.

Clinical pharmacist role in intercepting TRPs. Clinical pharmacists assessed TRPs, optimized treatment outcomes, and counselled patients to improve patient adherence to medications and self-care. They provided medication counselling, offered instructions on self-monitoring, and advised patients on healthy lifestyle choices. Educational materials including brochures and pamphlets were also offered to patients. On average patients, treatment related problems were 2.26-11.2.9,13,14,17,20,32,34,38,39 Pharmacist interventions were mainly to add a drug or prophylaxis therapy. ${ }^{9}, 13,14,17,18,20,39$ Physician acceptance rate ranged between $62 \%$ and $96 \%$. However, of those accepted by doctors, on average, 60\% were 
Table 1 - Characteristic of included studies and outcomes measured.

\begin{tabular}{|c|c|c|c|c|c|c|c|c|}
\hline \multirow[t]{2}{*}{ Authors (year) } & \multirow{2}{*}{$\begin{array}{c}\text { Study } \\
\text { duration } \\
\text { (months) }\end{array}$} & \multirow[t]{2}{*}{ Study design } & \multirow[t]{2}{*}{ Sample size } & \multirow[t]{2}{*}{ Setting } & \multicolumn{4}{|c|}{ Outcomes } \\
\hline & & & & & Ther & Saf & Hum & Econ \\
\hline Al-Azzam et al (2013) ${ }^{9}$ & 7 & Prospective uncontrolled & $\mathrm{n}=3,026$ & In & $\times$ & $x$ & $\times$ & $\times$ \\
\hline Al- Azzam et al $(2016)^{38}$ & 16 & Prospective uncontrolled & $\mathrm{n}=2,898$ & Out & $x$ & $\times$ & $x$ & $\times$ \\
\hline $\begin{array}{l}\text { Albsoul-Younes et al } \\
(2011)^{32}\end{array}$ & 6 & $\mathrm{RCT}$ & $\begin{array}{l}\text { Int: } n=130 \\
\text { Con: } n=123\end{array}$ & Out & $\sqrt{ }$ & $\times$ & $\times$ & $\times$ \\
\hline Abu Farha et al $(2015)^{39}$ & 3 & Prospective uncontrolled & $\mathrm{n}=200$ & Out & $\times$ & $\times$ & $\times$ & $\times$ \\
\hline Abuloha et al $(2016)^{33}$ & 6 & RCT & $\begin{array}{l}\text { Int: } n=50 \\
\text { Con: } n=50\end{array}$ & Out & $\sqrt{ }$ & $\sqrt{ }$ & $\sqrt{ }$ & $\times$ \\
\hline $\begin{array}{l}\text { Abu Oliem et al } \\
(2013)^{14}\end{array}$ & 7 & $\mathrm{RCT}$ & $\begin{array}{l}\text { Int: } \mathrm{n}=50 \\
\text { Con: } \mathrm{n}=52\end{array}$ & In & $\times$ & $\times$ & $\times$ & $\times$ \\
\hline AbuRuz et al $(2011)^{13}$ & 4 & Prospective uncontrolled & $\mathrm{n}=402$ & In & $\times$ & $\times$ & $\sqrt{ }$ & $\times$ \\
\hline AbuRuz et al $(2013)^{18}$ & 3 & Prospective before and after & $\mathrm{n}=130$ & In & $\times$ & $\times$ & $x$ & $\times$ \\
\hline Ahmad et al $(2014)^{22}$ & 5 & Prospective before and after & $\mathrm{n}=204$ & Out & $\times$ & $\times$ & $\sqrt{ }$ & $\times$ \\
\hline Aljbouri et al $(2013)^{12}$ & 20 & Prospective before and after & $\begin{array}{l}\text { Int: } \mathrm{n}=85 \\
\text { Con: } \mathrm{n}=86\end{array}$ & In & $\times$ & $\times$ & $\times$ & $\sqrt{ }$ \\
\hline Al Omari et al (2016) $)^{31}$ & 10 & Prospective uncontrolled & $\mathrm{n}=250$ & Out & $\sqrt{ }$ & $\times$ & $\times$ & $\times$ \\
\hline Basheti et al $(2013)^{17}$ & 3 & Prospective uncontrolled & $\mathrm{n}=167$ & Community & $\times$ & $\times$ & $\sqrt{ }$ & $\times$ \\
\hline Basheti et al $(2016)^{37}$ & 3 & RCT & $\begin{array}{l}\text { Int: } \mathrm{n}=48 \\
\text { Con: } \mathrm{n}=49\end{array}$ & Out & $\times$ & $\times$ & $\sqrt{ }$ & $\times$ \\
\hline Elyeah et al $(2014)^{24}$ & 3 & Before and after & $n=395$ & Community & $\times$ & $\times$ & $\sqrt{ }$ & $\times$ \\
\hline Hammad et al $(2011)^{11}$ & 6 & $\mathrm{RCT}$ & $\begin{array}{l}\text { Int: } n=110 \\
\text { Con: } n=89\end{array}$ & Out & $\sqrt{ }$ & $\times$ & $\times$ & $\times$ \\
\hline Jarab et al (2012) ${ }^{10}$ & 4 & $\mathrm{RCT}$ & $\begin{array}{l}\text { Int: } \mathrm{n}=85 \\
\text { Con: } \mathrm{n}=86\end{array}$ & Out & $\sqrt{ }$ & $\times$ & $\sqrt{ }$ & $\times$ \\
\hline Jarab et al (2012) ${ }^{35}$ & & RCT & $\begin{array}{l}\text { Int: } n=63 \\
\text { con: } n=64\end{array}$ & Out & $\sqrt{ }$ & $x$ & $\sqrt{ }$ & $\times$ \\
\hline Qudah et al $(2016)^{34}$ & 3 & RCT & $\begin{array}{l}\text { Int: } n==29 \\
\text { con: } n==27\end{array}$ & Out & $\sqrt{ }$ & $\times$ & $\sqrt{ }$ & $\times$ \\
\hline Tahaineh et al $(2011)^{20}$ & 6 & $\mathrm{RCT}$ & $\begin{array}{l}\text { Int: } \mathrm{n}==73 \\
\text { Con: } \mathrm{n}=52\end{array}$ & Out & $\sqrt{ }$ & $\sqrt{ }$ & $\times$ & $\times$ \\
\hline Tuffaha et al (2012) ${ }^{16}$ & 12 & Prospective uncontrolled & Not reported & Out & $\times$ & $\times$ & $\sqrt{ }$ & $\times$ \\
\hline Wishah et al $(2014)^{23}$ & 6 & RCT & $\begin{array}{c}\text { Int }(n=52) \\
\text { Con }(n=54)\end{array}$ & Out & $\sqrt{ }$ & $\times$ & $\sqrt{ }$ & $x$ \\
\hline
\end{tabular}

implemented. ${ }^{9,11,1316,17,31,35,37,38}$

The significant and direct clinical impacts on patient outcomes were often left unevaluated. Nevertheless, 2 studies by Aburuz et al, ${ }^{13,18}$ evaluated the clinical significance of TRPs. Over 4,000 TRPs were evaluated. Two-thirds of the TRPs were considered significant or major to moderate by 2 independent clinicians. Those that were considered extremely significant accounted for only $1 \%$. Al-Azzam et $\mathrm{al}^{38}$ reported results in increased quality/improved effect in 4,103 (30.8\%) cases, decreased cost in 233 (9.3\%), avoided adverse drug reaction/toxicity in $2,165(16.2 \%)$, and prevented medication error in 1,477 (11.1\%) TRPs. ${ }^{9}$ Abu Farha et $\mathrm{al}^{39}$ reported a significant association between poor blood pressure and increasing number of TRPs, where the mean TRPs of uncontrolled BP patients was 7.1 (2.4) and 5.1 (2.2) for controlled blood pressure patients; $p<0.05$.

Impact of clinical pharmacists on patient outcomes. Details of the outcomes measured and effects on therapeutic, safety, humanistic, and economic outcomes per study are presented in Appendix 2. Table 2 summarizes the clinical pharmacists' effects on selected outcomes.

Therapeutic outcomes. Blood pressure. Four studies have described the effect of pharmacists on BP 
Table 2 - Summary of clinical pharmacists effects on selected outcomes.

\begin{tabular}{|c|c|c|c|}
\hline Outcome & Authors, year & $\begin{array}{c}\text { Mean } \\
\text { difference }\end{array}$ & $\begin{array}{c}95 \% \mathrm{CI} \\
\text { (intervention } \\
\text { - control) }\end{array}$ \\
\hline \multirow{4}{*}{$\begin{array}{l}\text { SBP } \\
\text { reduction }\end{array}$} & Albsoul-Younes et al (2011) ${ }^{32}$ & 5.50 & $(2.04-8.96)$ \\
\hline & Hammad et al $(2011)^{11}$ & 4.54 & $(0.57-8.50)$ \\
\hline & Jarab et al $(2012)^{10}$ & 8.90 & $(0.70-17.10)$ \\
\hline & All studies & 5.45 & $(2.95-7.92)$ \\
\hline \multirow{4}{*}{$\begin{array}{l}\text { DBP } \\
\text { reduction }\end{array}$} & Albsoul-Younes et al (2011) ${ }^{32}$ & 3.33 & $(0.12-6.54)$ \\
\hline & Hammad et al $(2011)^{11}$ & 2.20 & $(-0.36-4.76)$ \\
\hline & Jarab et al $(2012)^{10}$ & 9 & $(1.16-16.84)$ \\
\hline & All studies & 3.03 & $(1.09-4.96)$ \\
\hline \multirow[t]{3}{*}{$\mathrm{HbA} \mathrm{1c}$} & Jarab et al $(2012)^{10}$ & 0.80 & $(0.14-1.47)$ \\
\hline & Wishah et al $(2014)^{23}$ & 0.70 & $(0.28-1.12)$ \\
\hline & All studies & 0.75 & $(-0.49-1.99)$ \\
\hline \multirow[t]{4}{*}{ FBS } & Hammad et al $(2011)^{11}$ & 4.80 & $(-7.92-17.50)$ \\
\hline & Jarab et al $(2012)^{10}$ & 43.30 & $(9.22-77.39)$ \\
\hline & Wishah et al $(2014)^{23}$ & 31.10 & $(17.85-44.35)$ \\
\hline & All studies & 36.73 & $(-19.67-93.14)$ \\
\hline \multirow[t]{3}{*}{ TC } & Jarab et al $(2012)^{10}$ & 30.89 & $(24.22-61.53)$ \\
\hline & Wishah et al $(2014)^{23}$ & 8.40 & $(3.59-20.39)$ \\
\hline & All studies & 18.63 & $(8.31-65.59)$ \\
\hline \multirow[t]{3}{*}{ LDL } & Jarab et al $(2012)^{10}$ & 0.70 & $(0.65-2.05)$ \\
\hline & Wishah $(2014)^{23}$ & 4.4 & $(-4.85-13.65)$ \\
\hline & All studies & 2.36 & $(1.8-16.62)$ \\
\hline \multirow[t]{4}{*}{ TG } & Hammad et al $(2011)^{11}$ & 30.10 & $(6.86-53.54)$ \\
\hline & Jarab et al $(2012)^{10}$ & 14.41 & $(10.21-27.61)$ \\
\hline & Wishah $(2014)^{23}$ & 16.9 & $(9.91-43.71)$ \\
\hline & All studies & 20.16 & $(6.14-46.47)$ \\
\hline \multirow[t]{4}{*}{ HDL } & Hammad et al $(2011)^{11}$ & 5.3 & $(2.7-7.5)$ \\
\hline & Jarab et al $(2012)^{10}$ & -0.15 & $(-0.69-0.99)$ \\
\hline & Wishah $(2014)^{23}$ & -1.5 & $(-4.8-1.8)$ \\
\hline & All studies & 1.24 & $(1.14-4.11)$ \\
\hline \multicolumn{4}{|c|}{$\begin{array}{l}\text { SBP - systolic blood pressure, DBP - diastolic blood pressure, } \\
\text { HbA 1c - glycosylated hemoglobin, FBS - fasting blood sugar, TC - total } \\
\text { cholesterol, HDL - high density lipoprotein, TG - triglyceride, } \\
\text { BMI - body mass index, LDL - low density lipoprotein }\end{array}$} \\
\hline
\end{tabular}

goals. ${ }^{10,32,34,35}$ Qudah et $\mathrm{al}^{34}$ assessed an average decline in mean home systolic BP in dialysis patients measured on a weekly base whilst the remainder evaluated an average reduction at 6 month follow up. A significant reduction was found in the intervention arm, $10.9 \pm 17.7 \mathrm{~mm} \mathrm{Hg}$ $(p=0.004)$. No significant reduction was achieved in weekly home and diastolic BP. Due to different outcomes measured, the results of Qudah et $\mathrm{al}^{34}$ were not pooled in the average BP estimate in Table 2.

Glycemic control. Three studies evaluated the effect on glycosylated hemoglobin (Hb A1c) over 6 months. ${ }^{10,23,33}$ diabetic patients who received clinical pharmacist services showed reduction whist those in the control group had an increase or less profound reduction. However, the pooled average was not statistically significant as seen in Table 2 .

Dyslipidemia. Four studies evaluated the impact of clinical pharmacists on lipids parameters. ${ }^{10,20,23,34}$ The average effects are presented in Table 2. The average reductions were significant for total cholesterol (TC), triglyceride (TG), and low density lipoprotein (LDL). ${ }^{10,11,23}$ There was a minimal increase in the level of high density lipoprotein (HDL). The study by Tahaineh et $\mathrm{al}^{20}$ assessed the achievement of targeted goals described by the National Cholesterol Education Program (NCEP/ATP III). There were not enough details to estimate the magnitudes of change. Thus, the results of Tahaineh et $\mathrm{al}^{20}$ was not pooled in the average effect.

Other therapeutic outcomes. Body mass index (BMI) and body weight. Three studies looked to the effect of clinical pharmacist on BMI over 6 months. The effect was shown a minimal and statistically not significant. ${ }^{10,23,36}$ Abuloha et $a^{33}$ evaluated weight gain in diabetic patients associated with insulin therapy modifications guided by focused clinical pharmacist interventions. There was a significant increase in weight mean whilst no significant increase was noticed in the control group. Hammad et $\mathrm{al}^{11}$ also reported no significant change in body weight over 6 months.

Metabolic syndrome status. Hammad et $\mathrm{al}^{11}$ looked at the effect of pharmacists on a collection of lifestyle risk factors that constitute metabolic syndrome, also called insulin resistance or syndrome $\mathrm{X}$. The definition was based on the NCEP/ATP III recommendations. Pharmacists' care helped to successfully shift patients from metabolic to non-metabolic syndrome $(p=0.032) .{ }^{10}$

Lung function in COPD patients. Jarab et $\mathrm{a}^{35}$ evaluated the impact of pharmaceutical care on patients with COPD over 6 months. Lung function did not change significantly in either group.

International normalized ratio (INR). Al-Omari et $\mathrm{al}^{31}$ evaluated the impact of clinical pharmacists on optimizing anticoagulation therapy. Out of 250 patients, $72 \%$ were referred to the clinic not achieving therapeutic INR. Of these, almost 45\% successfully reached the INR target within one week. By the end of 4th week, $92 \%$ of the patients achieved the target INR.

Safety outcomes. In the study by Abuloha et al, ${ }^{33}$ hypoglycemic episodes were evaluated. Within the first month of follow up, intervention patients had a higher odds ratio compared to the standard care with 2.49 compared to $1.12(p=0.016)$. However, at 2 and 3 months, no difference was shown. None of these hypoglycemic episodes resulted in hospitalization. Al-Omari et $\mathrm{al}^{31}$ looked to hospitalization and 


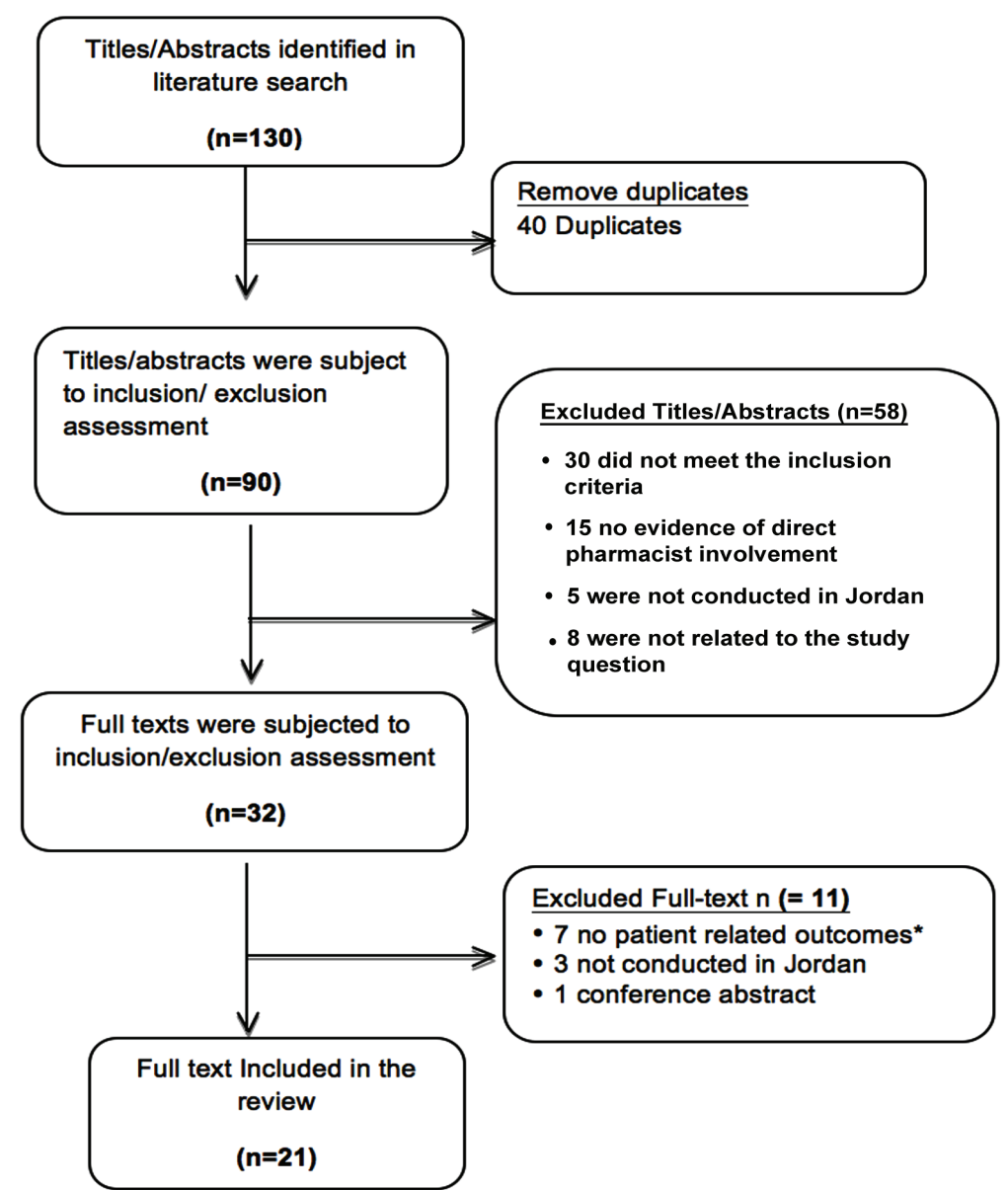

Figure 1 - The study screening and selection process. *for example perceived value of clinical pharmacist service in community settings, acceptability and feasibility outcomes.

emergency visits associated with warfarin therapy. None were reported over one month.

Humanistic outcomes. Knowledge and adherence to medication, disease management, and self-care activities. Pharmacist direct education to patients significantly improved knowledge scores 8.56 (4.69-21.83). ${ }^{10,23,24}$ Similarly, the 2 studies by Jarab et al, ${ }^{10,35}$ Wishah et al, ${ }^{23}$ and Basheti et $\mathrm{al}^{37}$ reported significant improvement in adherence to medications (all $p$-values were $>0.05$ ). Qudah et $\mathrm{al}^{34}$ evaluated the proportion of patients selfreporting high adherence to antihypertensive agents. Patients who were classified with "high adherence" were not clearly described. Nevertheless, no difference was found between the study groups $(p=0.18) .{ }^{34}$ Adherence to 4 diabetes self-care activities was also assessed by Jarab et $\mathrm{al}^{10}$ using a validated questionnaire. A significant improvement was reported in all domains except for foot care and smoking status. ${ }^{10}$ Basheti et al ${ }^{37}$ used the patient interview method and reported significant improvement in self-care activity scores $(p<0.001)$. Intradialytic percent weight gain indicating adherence to fluid and salt restriction was assessed by Qudah et al. ${ }^{34}$ There was no significant change in the study group. Due to the variability of the outcome measurement, the average adherence score was not pooled.

Health related quality of life. The impact of clinical pharmacists on the quality of life was assessed using a St George Respiratory Questionnaire, a validated and standardized self-administered 76-item instrument designed specifically for patients with chronic airways disease. Jarab et $\mathrm{al}^{35}$ identified improvement, but this was neither statistically nor clinically significant. Basheti et $\mathrm{al}^{37}$ used EQ-5D, a self-completed questionnaire 


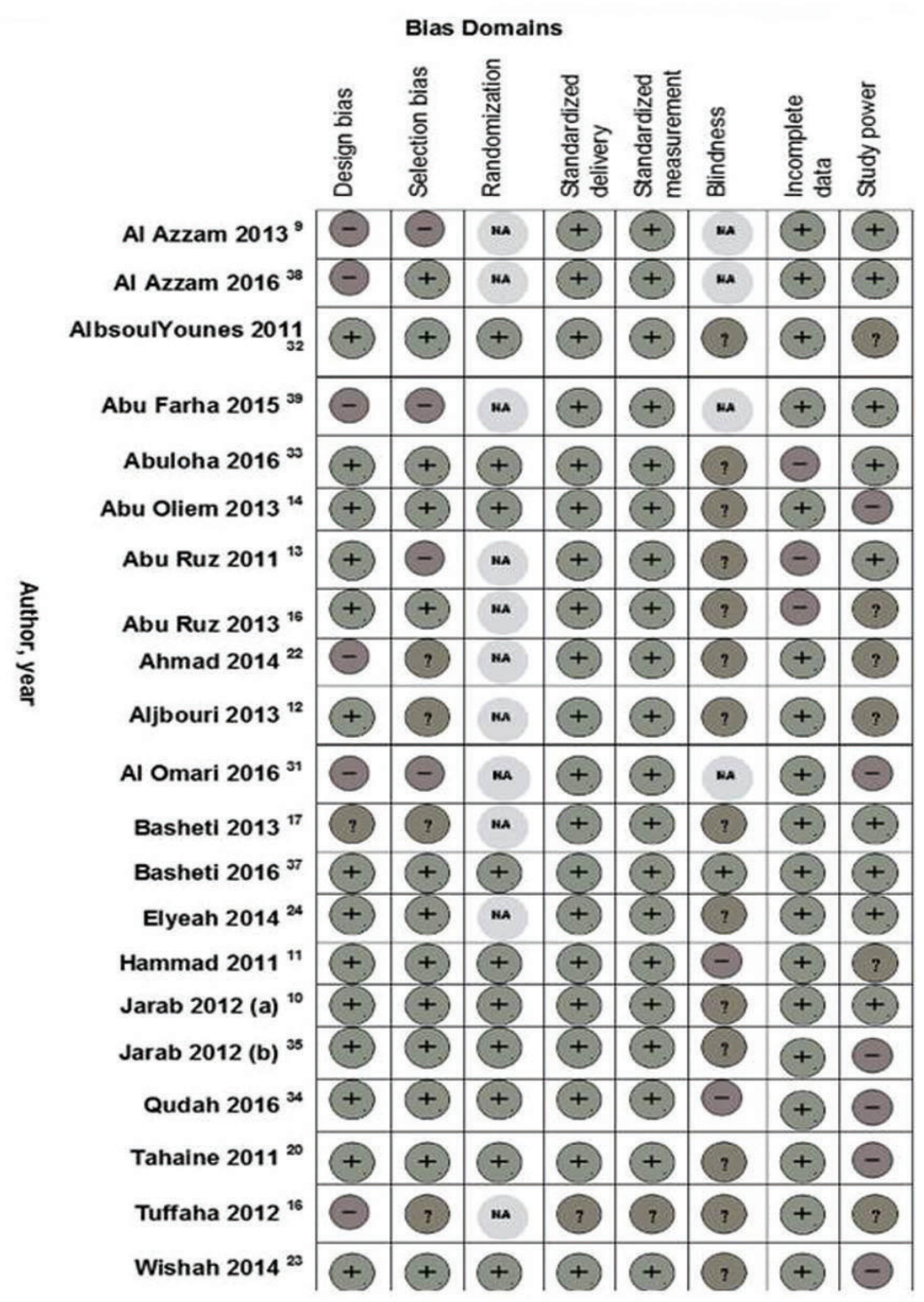

Figure 2 - Assessment of bias risk per study. (+) low risk of bias, (?) unclear/ no sufficient information (-) high risk of bias.

consisting of 5 domains: mobility, self-care, usual activities, pain/discomfort, and anxiety/depression. There was no significant improvement between the study groups at the end of the study $(p=0.44)$. The quality of life scores were based on data obtained from the UK. The extent to which these relate to the Jordanian population is unknown.

Economic outcomes. Aljbouri et $\mathrm{a}^{12}$ assumed that a decrease in the consumption rate of drugs is an indicator of the success of the clinical pharmacist service in the ICU. They estimated a $35.8 \%$ reduction in therapy costs. However, they did not weigh patients outcomes with the costs saved or consumed; thus, little can be concluded about the cost effectiveness of the service. Health resources utilization was assessed in COPD. The proportion of patients who had an emergency department visit for acute exacerbation of COPD decreased in the intervention group from $16.7 \%$ to $15.2 \%$ and increased in the control group from $16.4 \%$ to $17.9 \%$. This change was not statistically significant. Re-admissions to hospital was, on the other hand, reduced significantly; less than $5 \%$ were re-admitted in the intervention group compared to $16.4 \%$ in the control group $(p=0.031) .{ }^{35}$ 


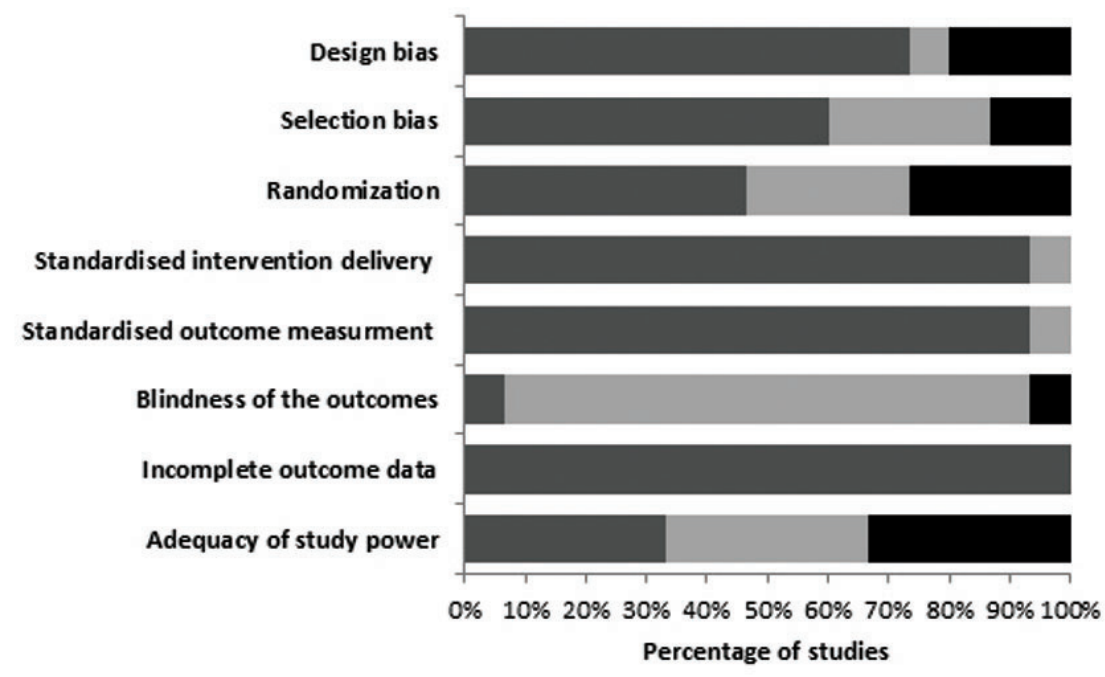

Figure 3 - Assessment of bias risk per bias domain. Black color: high risk of bias light. Shade gray: unclear bias. Dark shade of gray: low risk of bias.

Publication bias and heterogeneity. The funnel plots for BP and lipid parameter analysis did not suggest bias and Kendall's tau supported this interpretation ( $p=0.67$ and $p=0.46$ ). Whilst the funnel plots for the HbA1c and FBS analysis indicated low publication bias, Kendall's tau was $p=0.087$. Testing for heterogeneity, $\mathrm{I}^{2}$ for all outcomes was less than $50 \%$ with $95 \% \mathrm{CI}=15 \%-63 \%$. The study team re-examined the studies for substantial differences among study designs, characteristics of subjects, and pharmacist led intervention. Heterogeneity was agreed not substantial.

Discussion. To the best of our knowledge, no other systematic review exists that has broadly encompassed existing evidence for the role of pharmacists in an eastern Mediterranean country, particularly in a low income country such as Jordan. Pharmacy education is continuously evolving in Jordan, but the practice still falls behind. Portraying a similar picture as other developing countries, clinical pharmacy service is still at the grass-root level and the value of these services to patients and health systems is not well understood. ${ }^{40}$ Decision makers must understand the add-on benefits to patients and health systems in order to endorse practice changes. This review adds to the existing review summarizing the pharmacist's role and the evidence from middle income countries. ${ }^{27}$ Thus, it highlights the potential impacts of pharmacists on improving disease management and patient outcomes and highlights potential drivers for profession progress and future research for decision makers and researchers.
The reviewed studies were successful in identifying service opportunities. They were of moderate quality demonstrating methodological limitations manily with respect to selection bias, blindness of outcomes measured and adequacy of study power. Nevertheless, the clinical pharmacists had an important role in identifying and intercepting TRPs. However, direct impacts on patient safety and management were not evaluated. This is in line with the growing evidence from the US, UK, and Europe depicting the role of pharmacist's direct patient care on management and clinical outcomes. ${ }^{1,2}$ It is also consistent with findings from the evidence identified in middle-income countries in the Cochrane library. ${ }^{27}$ The mean effects among Jordanians; however, were lower for the reported therapeutic outcomes. Further evaluation is recommended to assess if this reflects factors related to the setting, pharmacy practice, study designs, or participants. Nevertheless, favorable effects but not always statistically significant ones were found. Impacts on safety, humanistic, and economic outcomes were not evaluated often; thus no conclusions were withdrawn. These outcomes are important to highlight the relevance of the profession to health systems and communities. Therefore, future studies evaluating multi-dimensional perspectives of outcomes are mandated. Evidence of the benefits of long term outcomes or complications such as mortality or cardiovascular (CV) events is lacking. ${ }^{3}$

Implications to practice and future research. Clinical pharmacy services appeared feasible within the context of the reviewed studies; clinical pharmacists were integrated in patient consultations and care optimization. They were equipped for the new roles 
and there was a pursuit for the goals of medicine management and pharmaceutical care. However, fully accepting these new roles by other members of the health team particularly doctors appeared challenging. This is, however, an ongoing issue since 2009. ${ }^{21,26}$ Resistance and lack of recognition for the clinical pharmacist role should be addressed effectively by multi-dispensary discussions, public education, and mixed profession undergraduate teaching. These are required to catalyze the process of advancing the profession of pharmacy. ${ }^{41}$ It is also important to formulate regulations enforcing and governing clinical pharmacy practice within both the community and hospitals. In Saudi Arabia, the Saudi Council for health specialties advanced the clinical pharmacy program by adopting a 2-year residency program of accredited training. Graduates passing a final exam are granted a board certification for clinical pharmacy. Capacity to adapt such an initiative in Jordan could be limited by the privatization of hospitals and community pharmacies. Thus the drivers to change must exist at higher levels of health and policy management to empower practice changes across governmental and private health services. Developed countries achieved safe, effective, and rational use of medicines by empowering pharmacists to take greater roles in patient management. ${ }^{42}$ In these countries, continuous professional development has become a driving feature of pharmacy practice. For instances, UK pharmacists are expected to undertake at least 30 hours of continuing professional development per year. ${ }^{43}$

Also, evaluating the economic impact of health interventions services provides an important driver for change. In Europe, for example, governments are increasingly looking at ways of controlling the costs of medicines. Medicines have been deregulated from prescription-only status to over the counter sale in most European countries. This implied substantial cost saving, because patients are increasingly seeking advice from pharmacists where previously they would have visited the doctor. Herein, clinical pharmacists have been proposed as a cost-effective alternative to their traditional roles. ${ }^{44,45}$

Noteworthy, challenges to practice progress in Jordan are similar to other developing countries. ${ }^{4,5,46}$ However, within the current context, changes are very possible. Pharmacy education in Jordan is thriving to meet international standards. ${ }^{47}$ Additionally, the status of pharmacy practice regulation and governess is advancing. The Ministry of Health in Jordan, along with the 2 main teaching hospitals and the leading cancer center has established independent divisions for pharmaceutical care service. These are providing clinical services via training Pharm.D. or Master students. With institutional laws and policies, staff and resources can be allocated to operate closely with patients and the care team in the future. The Jordan Food and Drug Association led by the Pharmacy and Drug Law in 2003, the highest official regulatory document for drug use and handling in Jordan, assign clinical pharmacists consultation roles in committees responsible for national drug registration and pricing decisions. Clinical Master graduates have been employed there for pharmacovigilance, drug information, and rational drug use. Herein, political and regulatory support is important to widen the uptake of clinical pharmacists and certainly is a key for profession progress. ${ }^{44,46,47}$

Limitations. This review included findings only from published articles. Reviews can overestimate population effects if unpublished studies were not included. Those unpublished, however, were not in a suitable format and quality for the review use. The search language and terms were in English language, but Arabic is the native spoken language in Jordan. Nevertheless, teaching and research are conducted and disseminated in English. Thus we anticipate no or little effects on the outcome and the conclusion of this review. The studies were not found heterogeneous with respect to the intervention, sample size, and settings, but there were variations in the outcomes measured. For each outcome, there were two to 3 studies only. Hence, a numerical summary of mean effects was plausible. Nevertheless, $\mathrm{I}^{2}$ might show a substantial bias when the number of studies is small. Thus, further studies are recommended. Additionally, this study focused on the evidence from Jordanian settings only. Evidence from nearby countries was not considered in this review due to variations in the health care systems, funding, population, and settings. Future reviews pooling the evidence in the Middle East area ought to focus on generic outcomes such as quality of life.

In conclusion, this review highlighted the roles of clinical pharmacist service in intercepting errors and potentials for improving patient outcomes. Much is still left to understand with respect to safety, humanistic, economic, and long term outcomes. Therefore, the add-on benefits of service uptake to the health system are not well understood. Future studies of higher rigor and evaluating multi-dimensional and long term outcomes are mandated in future studies. Evidence on cost-effectiveness must be sought too to enable informed decision making and resource allocation. 


\section{References}

1. Kaboli PJ, Hoth AB, McClimon BJ, Schnipper JL. Clinical pharmacists and inpatient medical care: a systematic review. Arch Intern Med 2006; 166: 955-964.

2. Chisholm-Burns MA, Kim Lee J, Spivey CA, Slack M, Herrier RN, Hall-Lipsy E, et al. US pharmacists' effect as team members on patient care: systematic review and meta-analyses. Med Care 2010; 48: 923-933.

3. Rotta I, Salgado TM, Silva ML, Correr CJ, Fernandez-Llimos F. Effectiveness of clinical pharmacy services: an overview of systematic reviews (2000-2010). Int J Clin Pharm 2015; 37 : 687-697.

4. Al-Wazaify M, Albsoul-Younes A. Pharmacy in Jordan. Am J Health Syst Pharm 2005; 62: 25-48.

5. Azhar S, Hassali M, Ibrahim MI, Ahmad M, Masood I, Shafie AA. The role of pharmacists in developing countries: the current scenario in Pakistan. Human Resources for Health 2009; 7: 54.

6. Bader LR, McGrath S, Rouse MJ, Anderson C. A conceptual framework toward identifying and analyzing challenges to the advancement of pharmacy. Res Social Adm Pharm 2017; 13: 321-331.

7. Bulatova NR, Aburuz S, Yousef AM. An innovative pharmaceutical care practical course. Adv Health Sci Educ Theory Pract 2007; 2: 211-222.

8. Al-Wazaify M, Matowe L, Albsoul-Younes A, Al-Omran OA. Pharmacy education in Jordan, Saudi Arabia, and Kuwait. Am J Pharm Educ 2006; 70: 18.

9. Al-azzam SI, Shara M, Alzoubi KH, Almahasneh FA, Iflaifel M. Implementation of clinical pharmacy services at a university hospital in Jordan. Int J Pharm Pract 2013; 21: 337-340.

10. Jarab AS, Alqudah SG, Mukattash TL, Shattat G, Al-Qirim T. Randomized controlled trial of clinical pharmacy management of patients with type 2 diabetes in an outpatient diabetes clinic in Jordan. J Manag Care Pharm 2012; 8: 516-526.

11. Hammad EA, Yasein N, Tahaineh L, Albsoul-Younes AM. A randomized controlled trial to assess pharmacist- physician collaborative practice in the management of metabolic syndrome in a University Medical Clinic in Jordan. J Manag Care Pharm 2011; 17: 295-303.

12. Aljbouri TM, Alkhawaldeh MS, Abu-Rumman AE, Hasan TH, Khattar HM, Abu-Oliem AS. Impact of clinical pharmacist on cost of drug therapy in the ICU. Saudi Pharm J 2013; 21 : 371-374.

13. Aburuz SM, Bulatova NR, Yousef AM, Al-Ghazawi MA, Alawwa IA, Al-Saleh A. Comprehensive assessment of treatment related problems in hospitalized medicine patients in Jordan. Int J Clin Pharm 2011; 33: 501-511.

14. Abu-Oliem AS, Al-Sharayri MG, AlJabra R, Hakuz NM. A Clinical Trial to investigate the role of clinical pharmacist in resolving/preventing drug related problems in ICU patients who receive anti-infective therapy. Jordan Journal of Pharmaceutical Sciences 2013; 6; 292-298.

15. Issa A, Abu Farha R, Elayeh E, Bustanji Y. The impact of lack of pharmacist contribution on the prescription patterns and the appropriateness of indications of NSAIDs, A cross-sectional study. Jordan Journal of Pharmaceutical Sciences 2013; 6: 258-269.

16. Tuffaha HW, Abdelhadi O, Al Omar S. Clinical pharmacy services in the outpatient pediatric oncology clinics at a comprehensive cancer center. Int J Clin Pharm 2012; 34: 27-31.
17. Basheti IA, Qunaibi EA, Bulatova NR, Samara S, AbuRuz S. Treatment related problems for outpatients with chronic diseases in Jordan: the value of home medication reviews. Int J Clin Pharm 2013; 35: 92-100.

18. AbuRuz SM, Alrashdan Y, Jarab A, Jaber D, Alawwa IA. Evaluation of the impact of pharmaceutical care service on hospitalized patients with chronic kidney disease in Jordan. Int J Clin Pharm 2013; 35: 780-789.

19. Basheti IA, Qunaibi E, Hamadi S, Abu-Gharbieh E, Saleh S, AbuRuz S, et al. Patient Perspectives of the Role of the Community Pharmacist in the Middle East: Jordan, United Arab Emirates and Iraq. Pharmacol Pharm 2014; 5: 588-599.

20. Tahaineh L, Albsoul-Younes A, Al-Ashqar E, Habeb A. The role of clinical pharmacist on lipid control in dyslipidemic patients in North of Jordan. Int J Clin Pharm 2011; 33: 229-236.

21. Tahaineh LM, Wazaify M, Albsoul-Younes A, Khader Y, Zaidan M. Perceptions, experiences, and expectations of physicians in hospital settings in Jordan regarding the role of the pharmacist. Res Social Adm Pharm 2009; 5: 63-70.

22. Ahmad DS. Wazaify M, Albsoul-Younes A. The Role of the Clinical Pharmacist in the Identification and Management of Corticophobia-An Interventional Study. Trop J Pharm Res 2014; 13: 445-453.

23. Wishah RA, Al-Khawaldeh O, Albsoul A. Impact of pharmaceutical care interventions on glycemic control and other health-related clinical outcomes in patients with type 2 diabetes: Randomized controlled trial. Diabetes Metab Syndr 2014; 9: 271-276.

24. Elayeh E, Akour A, Yousef AM, Basheti I. Osteoporosis amongst jordanians: effect of pharmacist-directed brochure education on people's knowledge. Trop J Pharm Res 2015; 13: 2101-2108.

25. Khdour MR, Jarab AS, Adas HO, Samaro EZ, Mukattash TL, Hallak HO. Identification of drug-related problems: a prospective study in two general hospitals. Curr Clin Pharmacol 2012; (4): 276-281.

26. Aburuz S, Al-Ghazawi M, Snyder A. Pharmaceutical care in a community-based practice setting in Jordan: where are we now with our attitudes and perceived barriers? Int J Pharm Pract 2012; 20: 71-79.

27. Pande S, Hiller JE, Nkansah N, Bero L. The effect of pharmacist-provided non-dispensing services on patient outcomes, health service utilisation and costs in low- and middle-income countries. Cochrane Database Syst Rev 2013; 2: CD010398.

28. Neyeloff JL, Fuchs SC, Moreira LB. Meta-analyses and Forest plots using a microsoft excel spreadsheet. BMC Research Notes 2012; 5: 1-6.

29. Hammad EA, Bale A, Wright DJ, Bhattacharya D. Pharmacy led medicine reconciliation at hospital: A systematic review of effects and costs. Res Social Adm Pharm 2017; 13: 300-312.

30. Santschi V, Chiolero A, Colosimo AL, Platt RW, Taffé P, Burnier $\mathrm{M}$, et al. Improving blood pressure control through pharmacist interventions: a meta-analysis of randomized controlled trials. J Am Heart Assoc 2014; 3: e000718.

31. Al-Omari N, Nairooz N, Ayesh HR, Al-Sarayreh $\mathrm{H}$, Al-Haqesh H, Ibrahim D. An audit evaluating anticoagulation clinic managed by clinical pharmacists in Jordan. The Egyptian Journal of Hospital Medicine 2016; 62: 89-94. 
32. Albsoul-Younes AM, Hammad EA, Yasein NA, Tahaineh LM. Pharmacist-physician collaboration improves blood pressure control. Saudi Med J 2011; 32: 288-292.

33. Abuloha S, Alabbadi I, Albsoul-Younes A, Younes N, Zayed A. The role of clinical pharmacist in initiation and/or dose adjustment of insulin therapy in diabetic patients in outpatient clinic in Jordan. Jordan Journal of Pharmaceutical Sciences 2016; 9: 33-50.

34. Qudah B, Albsoul-Younes A, Alawa E, Mehyar N. Role of clinical pharmacist in the management of blood pressure in dialysis patients. Int J Clin Pharm 2016; 38: 931-940.

35. Jarab AS, Alqudah SG, Khdour M, Shamssain M, Mukattash TL. Impact of pharmaceutical care on health outcomes in patients with COPD. Int J Clin Pharm 2012; 34: 53-62.

36. Albsoul-Younes A, Wazaify M, Alkofahi A. Pharmaceutical care education and practice in Jordan in the New Millennium. Jordan Journal of Pharmaceutical Science 2008; 1: 83-88.

37. Basheti IA, Al-Qudah RA, Obeidat NM, Bulatova NR. Home medication management review in outpatients with chronic diseases in Jordan: a randomized control trial. Int J Clin Pharm 2016; 38: 404-413.

38. Al-Azzam SI, Alzoubi KH, AbuRuz S, Alefan Q. Drug-related problems in a sample of outpatients with chronic diseases: a cross-sectional study from Jordan. Ther Clin Risk Manag 2016; 12: 233-239.

39. Abu Farha R, Basheti I, Abu Al Ruz H, et al Assessment of drug-related problems and their impact on blood pressure control in patients with hypertension Eur J Hosp Pharm 2016; 23: $126-130$.
40. Khan T, Anwar M, Ahmed K. A perspective for clinical pharmacy curriculum development and validation in Asian developing nations. J Young Pharm 2011; 3: 151-154.

41. Abdalla A, Abdelaal G, Mohamed E. Physicians perception about the role of clinical pharmacists and potential barriers to clinical pharmacy. World J Pharm Pharm Sci 2015; 4: 61-72.

42. Anderson $S$. The state of the world's pharmacy: a portrait of the pharmacy profession. J Interprof Care 2002; 6: 391-404.

43. Royal Pharmaceutical Society of Great Britain. Medicines, ethics and practice: a guide for pharmacists. [Updated 2016 July; Accessed 2017 May 8]. Available from: http://www. pharmpress.com/product/9780857112965/mep.

44. Schumock GT, Butler M, Meek P, Vermeulen LC, Arondekar BV. Bauman JL. Evidence of the economic benefit of clinical pharmacy services: 1996-2000. Pharmacotherapy 2003; 23: 113-132.

45. Yu J, Shah BM, Ip EJ, Chan J. A Markov model of the costeffectiveness of pharmacist care for diabetes in prevention of cardiovascular diseases: evidence from Kaiser Permanente Northern California. J Manag Care Pharm 2013; 19: 102-114.

46. Abduelkarem AR. Extending the role of pharmacists in patient care: Are pharmacists in developing nations ready to change? Pharmacol Pharm 2014; 5: 865-875.

47. University of Jordan. The Accreditation Council for Pharmacy Education (ACPE) has awarded the University of Jordan (UJ) School of Pharmacy full certification status. [Updated 2016 July. Accessed 2017 October 19th]. Available at: http://pharmacy.ju.edu.jo/Lists/AcademicNews/Disp_News. aspx?ID=32 
Appendix 1 - Characteristics of included patients.

\begin{tabular}{|c|c|c|c|c|}
\hline References & Age* $^{*}$ & Gender male n (\%) & Medication type & Disease area/ward \\
\hline Al- Azzam (2013) ${ }^{9}$ & Not reported & Not reported & Any & $\begin{array}{l}\text { ICU, CCU, internal medicine*, } \\
\text { and pediatrics }\end{array}$ \\
\hline Al- Azzam $(2016)^{38}$ & $56.59 \pm 13.5$ & $1,162(40.1)$ & Chronic use medicines & $\begin{array}{l}\text { cardiology, endocrine, and } \\
\text { respiratory }\end{array}$ \\
\hline Albsoul-Younes $(2011)^{32}$ & $\begin{array}{c}\text { Int } 56.3 \pm 9.6 \\
\text { Con } 57.5 \pm 11.9\end{array}$ & $\begin{array}{l}\text { Int } 61(46.9) \\
\text { Con: } 59(48.0)\end{array}$ & Anti-HTN & HTN \\
\hline Abu Farha $(2015)^{39}$ & $59.7 \pm 10.2$ & $79(39.5)$ & Anti-HTN & HTN \\
\hline Abuloha $(2016)^{33}$ & $\begin{array}{c}\text { Int } 54.71 \pm 10 \\
\text { Con } 56.51 \pm 10.4\end{array}$ & $\begin{array}{l}\text { Int } 19(42.2) \\
\text { Con } 18(41.9)\end{array}$ & Anti DM & $\mathrm{DM}$ \\
\hline Abu Oliem $(2013)^{14}$ & $\begin{array}{l}\text { Int } 54.7 \pm 18.9 \\
\text { Con } 52 \pm 19.1\end{array}$ & $\begin{array}{l}\text { Int } 25(48.1) \\
\text { Con: } 29(58)\end{array}$ & Antimicrobial & ICU \\
\hline $\operatorname{AbuRuz}(2011)^{13}$ & $\begin{array}{l}\text { Int } 54.5 \pm 16.9 \\
\text { Con - }\end{array}$ & $\begin{array}{l}\text { Int: } 195(48.5) \\
\text { Con: - }\end{array}$ & Any & Internal medicine* \\
\hline AbuRuz $(2013)^{18}$ & $\begin{array}{l}\text { Int } 56.3 \pm 17.8 \\
\text { Con - }\end{array}$ & $\begin{array}{c}\text { Int } 74(56.9) \\
\text { Con - }\end{array}$ & $\begin{array}{l}\text { BB, CCB, insulin, statin, ACEI, } \\
\text { Vitamin D, aspirin, ISDN, } \\
\text { CaCo3, ARBs, ferrous gluconate }\end{array}$ & Chronic kidney disease \\
\hline Ahmad $(2014)^{22}$ & $\begin{array}{l}\text { Int } 34.4 \pm 12.2 \\
\text { Con: - }\end{array}$ & $\begin{array}{l}\text { Int: } 88(43.1) \\
\text { Con: - }\end{array}$ & Corticosteroids & Not reported \\
\hline Aljbouri $(2013)^{12}$ & Not reported & Not reported & $\begin{array}{l}\text { Anti-infective and Cardiovascular } \\
\text { drugs. (Parenteral dosage form) }\end{array}$ & ICU \\
\hline Al Omari $(2016)^{31}$ & $\begin{array}{c}18 \text { - } 60 \text { years: } 177(70.8) \\
\text { >60 years: } 62(24.8) \\
\text { Int: } 58.9 \pm 13.54\end{array}$ & $\begin{array}{c}163(65) \\
\text { Int: } 89(53.3)\end{array}$ & Warfarin & $\begin{array}{c}\text { Anticoagulation Clinic/ Heart } \\
\text { institute } \\
\text { HTN, DM and CHD }\end{array}$ \\
\hline Basheti $(2013)^{17}$ & Con: - & Con: - & & \\
\hline Basheti $(2016)^{37}$ & $\begin{array}{c}\text { Int: } 63.13 \pm 7.99 \\
\text { Con: } 58.39 \pm 12.80\end{array}$ & $\begin{array}{l}\text { Int: } 17(35.4) \\
\text { Con: } 12(24.5)\end{array}$ & Chronic use medications & Not reported \\
\hline Elyeah $2014^{24}$ & $\begin{array}{l}\text { Int: } \\
\text { 18-29 years: } 182(47.1 \%) \\
\text { 30-49 years: } 98(25.4 \%) \\
\text { 50-60 years: } 79(20.5 \%) \\
\text { >60 years: } 27(7.0 \%) \\
\text { Con: - }\end{array}$ & $\begin{array}{l}\text { Int: } 117(29.6 \%) \\
\text { Con: - }\end{array}$ & Not reported & Osteoporosis \\
\hline Hammad $(2011)^{11}$ & $\begin{array}{c}\text { Int: } 56.0 \pm 9.6 \\
\text { Con: } 57.4 \pm 11.5\end{array}$ & $\begin{array}{l}\text { Int: } 44(40 \%) \\
\text { Con: } 32(46 \%)\end{array}$ & $\begin{array}{c}\text { Anti-HTN and lipid lowering } \\
\text { agents }\end{array}$ & Metabolic syndrome \\
\hline Jarab $(2012)^{10}$ & $\begin{array}{l}\text { Int: } 63.4 \pm 10.1 \\
\text { Con: } 65.3 \pm 9.2\end{array}$ & $\begin{array}{l}\text { Int: } 26(39.4 \%) \\
\text { Con: } 28(41.8 \%)\end{array}$ & $\begin{array}{l}\text { Anti DM, anti-HTN and lipid } \\
\text { lowering agents }\end{array}$ & $\mathrm{DM}$ \\
\hline Jarab $(2012)^{34}$ & $\begin{array}{l}\text { Int: 61(14) } \\
\text { Con: } 64(15)\end{array}$ & $\begin{array}{l}\text { Int: } 26(39.4) \\
\text { Con: } 28(41.8)\end{array}$ & $\begin{array}{c}\text { Bronchodilators, } \\
\text { inhaled and oral steroids } \\
\text { antibiotics }\end{array}$ & COPD \\
\hline Qudah (2016) ${ }^{34}$ & $\begin{array}{l}\text { Int: } 55.3 \pm 15.1 \\
\text { Con: } 51.7 \pm 18.5\end{array}$ & $\begin{array}{l}\text { Int: } 17(58.6) \\
\text { Con: } 18(66.7)\end{array}$ & Anti-HTN & Dialysis unit \\
\hline Tahaineh $(2011)^{20}$ & $\begin{array}{c}\text { Int: } 52.9 \pm 8.3 \\
\text { Con: } 52.8 \pm 8.5\end{array}$ & $\begin{array}{l}\text { Int: } 34.0(46.6 \%) \\
\text { Con: } 21.0(40.4 \%)\end{array}$ & $\begin{array}{l}\text { Lipid lowering agent } \\
\text { + anti HTN agents }\end{array}$ & $\begin{array}{l}\text { DM, CHD, HTN, } \\
\text { hypothyroidism }\end{array}$ \\
\hline Tuffaha $(2012)^{16}$ & Not reported & Not reported & Chemotherapeutic agents & cancer \\
\hline Wishah $(2014)^{23}$ & $\begin{array}{c}\text { Int: } 52.9 \pm 9.6 \\
\text { Con: } 53.2 \pm 11.2 \\
\end{array}$ & $\begin{array}{l}\text { Intervention: } 20(38.5 \%) \\
\text { Control: } 26(48.1 \%)\end{array}$ & Anti DM & $\mathrm{DM}$ \\
\hline \multicolumn{5}{|c|}{$\begin{array}{l}\text { *mean } \pm \text { SD, median. (IQR) or n (\%) as appropriate.** including cardiovascular, respiratory, nephrology, neurology, gastroenterology, infectious, } \\
\text { rheumatology, endocrinology, and oncology. Int - intervention group, Con - control group, HTN - hypertension, DM - diabetes mellitus, } \\
\text { CHD - chronic heart disease, COPD - chronic obstructive pulmonary disease, ICU - intensive care unit, CCU - cardiac/coronary care unit, } \\
\text { DM - diabetes mellitus, ISDN - isosorbide dinitrate, BB - beta-blockers, CCB - calcium channel blockers, ACEI - angiotensin converting enzyme } \\
\text { inhibitor, CaCo3 - calcium carbonate, ARBs - angiotensin II receptor blockers }\end{array}$} \\
\hline
\end{tabular}


Value of clinical pharmacists in Jordan ... Hammad et al

Appendix 2 - Summary of the clinical pharmacist effect on Jordanian patients' outcomes.

\begin{tabular}{|c|c|c|c|c|}
\hline \multirow{2}{*}{ Author, year } & \multicolumn{3}{|c|}{ Outcomes measured } & \multirow[b]{2}{*}{ Economic } \\
\hline & Therapeutic & Safety & Humanistic & \\
\hline Al- Azzam et al $(2013)^{9}$ & - & - & - & - \\
\hline Al- Azzam et al $(2016)^{38}$ & - & - & - & - \\
\hline Albsoul-Younes et al (2011) 32 & $\begin{array}{c}\text { BP goals }{ }^{1}(+) \\
\text { SBP \& DBP }(+)\end{array}$ & - & - & - \\
\hline Abu Farha et al $(2015)^{39}$ & - & - & - & - \\
\hline Abuloha et al (2016) ${ }^{33}$ & $\begin{array}{l}\text { FBG }(+) \\
\text { HbA1C }(+) \\
\text { Weight }(-)\end{array}$ & Hypoglycemia $^{2}(\mathrm{NE})$ & $\begin{array}{c}\text { Adherence (?) } \\
\text { Self-care (?) }\end{array}$ & - \\
\hline Abu Oliem et al (2013) ${ }^{14}$ & - & - & - & - \\
\hline AbuRuz et al $(2011)^{13}$ & - & - & $\begin{array}{l}\text { Adherence, knowledge and self- } \\
\text { care activities (?) }\end{array}$ & - \\
\hline AbuRuz et al $(2013)^{18}$ & - & Safety TRPs & - & - \\
\hline Ahmad et al $(2014)^{22}$ & - & & $\begin{array}{c}\text { Compliance }(+) \\
\text { Fear and corticophobia }(+)\end{array}$ & - \\
\hline Aljbouri et al $(2013)^{12}$ & - & - & - & Medicatin cost $(+)$ \\
\hline $\mathrm{Al}$ Omari et al $(2016)^{31}$ & INR & - & - & - \\
\hline Basheti et al $(2013)^{17}$ & - & - & - & \\
\hline Basheti et al $(2016)^{37}$ & - & - & $\begin{array}{l}\text { Adherence }(+) \\
\text { Self-care }(+)\end{array}$ & \\
\hline Elyeah et al $(2014)^{24}$ & - & - & Knowledge (+) & \\
\hline Hammad et al $(2011)^{11}$ & $\begin{array}{c}\text { MS status }(+) \\
\text { Waist circumference } \\
\text { TG }(+) \\
\text { HDL } \\
\text { FBS }(+) \\
\text { SPB \& DPB }(+) \\
\text { Body weight }\end{array}$ & - & - & - \\
\hline Jarab et al $(2012)^{10}$ & $\begin{array}{c}\text { HbA1c (+) } \\
\text { FBS (+) } \\
\text { LDL, TC, TG (+) } \\
\text { HDL } \\
\text { BMI } \\
\text { SBP \& DBP (+) }\end{array}$ & - & $\begin{array}{l}\text { Adherence }(+) \\
\text { Self-care }(+)\end{array}$ & - \\
\hline Jarab et al $(2012)^{35}$ & $\begin{array}{l}\text { FEV1 (NE) } \\
\text { BMI (NE) }\end{array}$ & & $\begin{array}{c}\text { HRQL (NE) } \\
\text { Satisfaction }^{3} \\
\text { Knowledge }(+) \\
\text { Adherence }(+)\end{array}$ & $\begin{array}{l}\text { ED visits (NE) } \\
\text { Readmission }(+)\end{array}$ \\
\hline Qudah et al (2016) ${ }^{34}$ & $\begin{array}{c}\text { Predialysis BP (NE) } \\
\text { Postdialysis BP (NE) } \\
\text { Intradialysis BP } \\
\text { Interdialytic weight gain (NE) } \\
\text { Home SBP }(+) \\
\text { Home DBP }(\mathrm{NE})\end{array}$ & - & Adherence to medications $(\mathrm{NE})^{4}$ & - \\
\hline Tahaineh et al $(2011)^{20}$ & $\begin{array}{c}\text { TC, } \mathrm{LDL}, \mathrm{HDL}(+) \\
\text { TG }\end{array}$ & Safety and adverse effects (?) & - & - \\
\hline $\begin{array}{l}\text { Tuffaha }(2012)^{16} \\
\text { Wishah }(2014)^{23}\end{array}$ & $\begin{array}{c}- \\
\text { HbAlc }(+) \\
\text { FBS }(+) \\
\text { LDL, HDL, TG (NE) } \\
\text { BMI (NE) }\end{array}$ & - & $\begin{array}{c}\text { Knowledge } \\
\text { Adherence to medications } \\
\text { Adherence to self-care }\end{array}$ & \\
\hline $\begin{array}{r}{ }^{1} \mathrm{BP} \text { goals as recommendec } \\
\text { pressure. }{ }^{2} \text { Rate of hypoglyce } \\
\text { and } 3 \text { months, no difference } \\
{ }^{4} \text { Interdialytic percent weight g. } \\
\text { no enough details, (NE) }=\mathrm{nc} \\
\text { TG - triglyceride, LDL - low d } \\
\text { sugar, FE }\end{array}$ & $\begin{array}{l}\text { the seventh report of the Joint } \mathrm{N} \\
\text { episodes was higher in the first } \mathrm{m} \\
s \text { shown with respect to hypoglyc } \\
\text { reflected adherence to fluid and sa } \\
\text { nificant effect. BP - blood pressu } \\
\text { ity lipoprotein, HDL - high dens } \\
\text { Forced expiratory volume-1, HR }\end{array}$ & $\begin{array}{l}\text { ational committee on preventic } \\
\text { onth of follow up in the interve } \\
\text { mic episodes among both grou } \\
\text { lt restriction. (+) = significant, } \\
\text { e, SBP - systolic blood pressure } \\
\text { ty lipoprotein, BMI - body ma } \\
\text { QL - Health-Related Quality o }\end{array}$ & $\begin{array}{l}\text { n,detection, evaluation and treatmer } \\
\text { ntion group compared to standard c } \\
\text { s, p }>0.05 .{ }^{3} \text { Self ratting of the effect } \\
\text { effect in favor of intervention group, } \\
\text { DBP - diastolic blood pressure, TC } \\
\text { s, index, HbA1c - Hemoglobin A1c, } \\
\text { Life, ED - Emergency Department }\end{array}$ & $\begin{array}{l}\text { t of high blood } \\
\text { are. However, at } 2 \\
\text { iveness of COPD. } \\
\text { (?) = unclear effect/ } \\
\text { - total cholesterol, } \\
\text { FBS - fasting blood }\end{array}$ \\
\hline
\end{tabular}

